\title{
Kallmann's syndrome: a visual vignette
}

\author{
Felix K Jebasingh, Riddhi Dasgupta, Nihal Thomas
}

Department of Endocrinology, Diabetes and Metabolism, Christian Medical College, Vellore, Tamil Nadu, India

\section{Correspondence to}

Dr Nihal Thomas,

nihal_thomas@yahoo.com

Accepted 16 August 2015

\section{DESCRIPTION}

Kallmann's syndrome is a rare form of idiopathic hypogonadotropic hypogonadism; impaired sense of smell and absent olfactory bulb are the hallmarks of this disease. ${ }^{12} \mathrm{~A} 20$-year-old man presented to us for evaluation of symptoms of a small-sized penis and testis, and poorly developed secondary sexual characteristics. His birth history revealed that he had been born with a cleft lip and cleft palate. The cleft lip was surgically corrected when he was 4 years of age. His current clinical examination revealed the presence of a surgically corrected cleft lip, and a cleft palate that had not received surgical

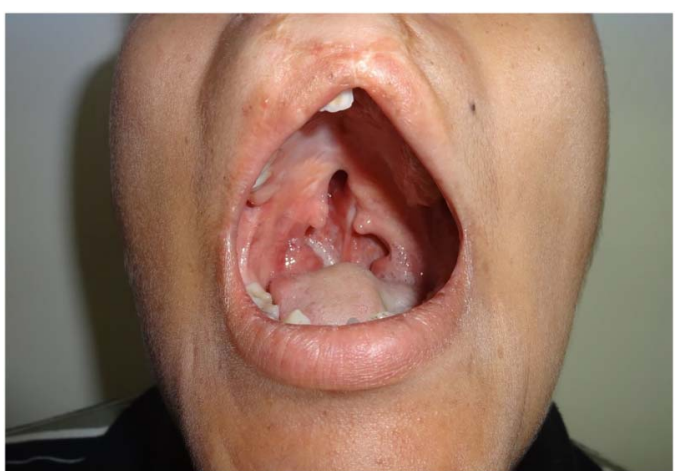

Figure 1 Picture of the patient showing the presence of a cleft palate.

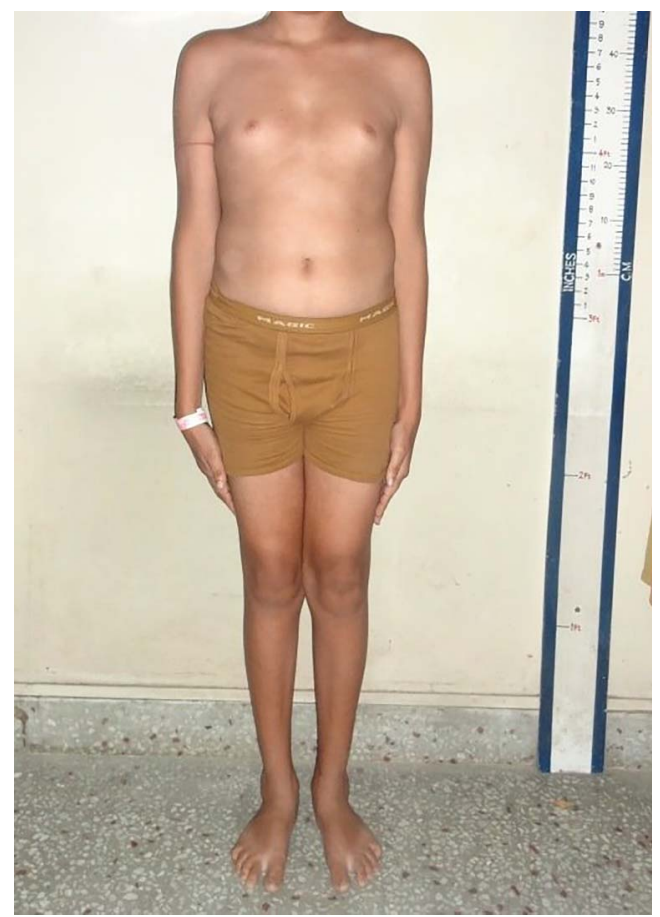

Figure 2 Picture of the patient showing a tall eunuchoid appearance without other skeletal abnormalities. correction (figure 1), with evidence of hyposmia. He had eunuchoidal body proportions with an arm span and height difference of $15 \mathrm{~cm}$ and an upper segment to lower segment ratio of $74 / 88 \mathrm{~cm}$ (figure 2). He had a stretched penile length of $5 \mathrm{~cm}$ and testicular volume was $2 \mathrm{~mL}$ bilaterally, with a Tanner stage 3 pubic hair level (figure 3). Laboratory tests showed serum luteinising hormone $<0.10 \mathrm{mIU} / \mathrm{mL}$ and follicle-stimulating hormone $0.325 \mathrm{mIU} / \mathrm{mL}$ with early morning serum testosterone of $<20.0 \mathrm{ng} / \mathrm{dL}$. The other hormonal axes were normal. MRI of the brain revealed a normal-sized pituitary gland with an absent olfactory bulb bilaterally (figure 4). The patient's clinical and biochemical features of idiopathic hyposmic hypogonadotropic hypogonadism was suggestive of Kallmann's syndrome. Defective migration of

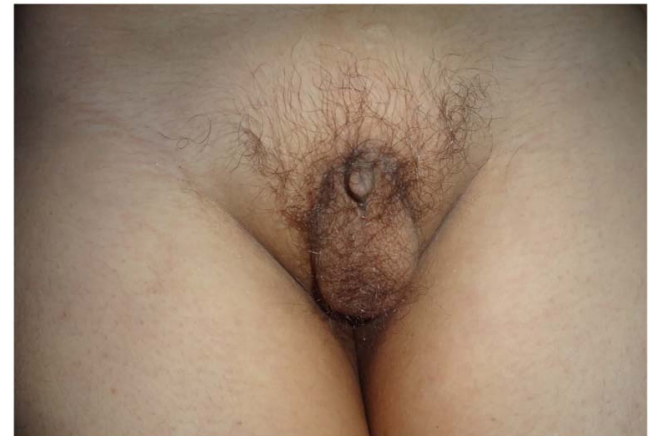

Figure 3 Picture of the external genitalia showing poorly developed pubic hair (Tanner's stage 3 ), small penis $(5 \mathrm{~cm})$ and bilaterally palpable testis $(2 \mathrm{~mL}$ measured by Prader's orchidometer).

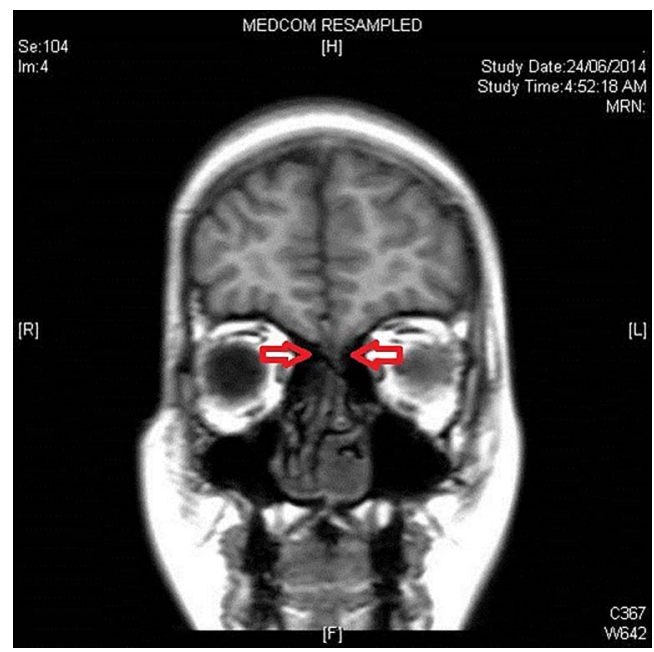

Figure 4 T1-weighted MRI (contrast enhanced) of the brain showing evidence of bilateral absence of olfactory bulbs (shown with arrows). 
gonadotropin-releasing hormone $(\mathrm{GnRH})$ neurons along with olfactory neurons results in an agenesis of olfactory bulb and gonadotropin deficiency. ${ }^{3}$ The patient was initially started on $100 \mathrm{mg}$ testosterone injections once every 3 weeks, with a plan to gradually escalate the dose to $250 \mathrm{mg}$.

\section{Learning points}

A cleft lip and cleft palate at birth are definite signs of Kallmann's syndrome.

- Impaired sense of smell distinguishes Kallmann's syndrome from most other forms of hypogonadotropic hypogonadism.
Contributors FKJ saw the patient and wrote the manuscript. RD saw the patient and helped write the manuscript. NT helped correct the manuscript.

Competing interests None declared.

Patient consent Obtained.

Provenance and peer review Not commissioned; externally peer reviewed.

\section{REFERENCES}

1 Gurdasani D, Surendrababu NRS, Paul TV. An interesting case of hypogonadism. Hong Kong Med J 2008;14:244-5.

2 Dodé C, Hardelin J-P. Kallmann syndrome. Eur J Hum Genet 2008;17:139-46.

3 Shetty S, Kapoor N, John RA, et al. Olfactory agenesis in Kallmann syndrome (KS). J Clin Diagn Res 2015;9:0J01.

Copyright 2015 BMJ Publishing Group. All rights reserved. For permission to reuse any of this content visit http://group.bmj.com/group/rights-licensing/permissions.

BMJ Case Report Fellows may re-use this article for personal use and teaching without any further permission.

Become a Fellow of BMJ Case Reports today and you can:

- Submit as many cases as you like

- Enjoy fast sympathetic peer review and rapid publication of accepted articles

- Access all the published articles

- Re-use any of the published material for personal use and teaching without further permission

For information on Institutional Fellowships contact consortiasales@bmjgroup.com

Visit casereports.bmj.com for more articles like this and to become a Fellow 